\title{
Automated system of seedling image analysis (SVIS) and electrical conductivity to assess sun hemp seed vigor ${ }^{1}$
}

\author{
Clíssia Barboza da Silva2*, Magnólia de Mendonça Lopes², \\ Julio Marcos-Filho ${ }^{3}$, Roberval Daiton Vieira ${ }^{2}$
}

\begin{abstract}
The development of new procedures for quickly obtaining accurate information on the physiological potential of seed lots is essential for developing quality control programs for the seed industry. In this study, the effectiveness of an automated system of seedling image analysis (Seed Vigor Imaging System - SVIS) in determining the physiological potential of sun hemp seeds and its relationship with electrical conductivity tests, were evaluated. SVIS evaluations were performed three and four days after sowing and data on the vigor index and the length and uniformity of seedling growth were collected. The electrical conductivity test was made on 50 seed replicates placed in containers with $75 \mathrm{~mL}$ of deionised water at $25^{\circ} \mathrm{C}$ and readings were taken after 1, 2, 4, 8 and 16 hours of imbibition. Electrical conductivity measurements at 4 or 8 hours and the use of the SVIS on 3-day old seedlings can effectively detect differences in vigor between different sun hemp seed lots.
\end{abstract}

Index terms: Crotalaria juncea, seedling image, software.

\section{Sistema automatizado de análise de imagens (SVIS) e condutividade elétrica para avaliação do vigor de sementes de crotalária}

\begin{abstract}
RESUMO - O desenvolvimento de novos procedimentos para rápida obtenção de informações precisas sobre o potencial fisiológico é essencial para o desenvolvimento de programas de controle de qualidade pelas empresas produtoras de sementes. Neste estudo, a eficácia de um sistema automatizado de análise de imagens de plântulas (Seed Vigor Imaging System - SVIS) na determinação do potencial fisiológico de sementes de crotalária, bem como sua associação com o teste de condutividade elétrica foram avaliados. As avaliações pelo SVIS foram feitas aos três e quatro dias após a semeadura e dados referentes a índice de vigor, comprimento e uniformidade do crescimento das plântulas foram coletados. O teste de condutividade elétrica foi realizado em repetições de 50 sementes colocadas em recipientes contendo $75 \mathrm{~mL}$ de água desionizada, a $25^{\circ} \mathrm{C}$ e as leituras, realizadas após 1,2 , 4, 8 e 16 horas de embebição. As medidas de condutividade elétrica com 4 ou 8 horas e o uso do SVIS em plântulas com três dias de idade podem detectar efetivamente diferenças no vigor de diferentes lotes de sementes de crotalária.
\end{abstract}

Termos para indexação: Crotalaria juncea, imagem de plântulas, software.

${ }^{1}$ Submitted on 04/21/2011. Accepted for publication on 05/24/2011.

${ }^{2}$ Departamento de Produção Vegetal, UNESP/FCAV, 14884-900, Jaboticabal-SP, Brasil.
${ }^{3}$ Departamento de Produção Vegetal, USP/ESALQ, Caixa Postal 9, 13418-900, Piracicaba, SP, Brasil.

*Corresponding author <clissia_unesp@yahoo.com.br> 


\section{Introduction}

Sun hemp (Crotalaria juncea L.) is an important legume used as a summer crop for green manure. It is adapted to dry conditions and grown worldwide because of its very high nitrogen-fixing potential (Wang et al., 2009). It also protects soils against erosion, reduces soil compaction, promotes significant nutrient recycling, suppresses pathogens, weeds and nematodes and supplies high quality fiber for manufacturing specialized paper products.

In spite of the importance and growing use of this legume, there are few data on germination and seed vigor testing. The evaluation of the physiological potential is important to guarantee the correct stand establishment of any seed-grown crop and, therefore, information on germination under optimal conditions (Brasil, 2009) should be obtained from one or more vigor tests.

Various tests have been developed and improved to assess the seed vigor of many species in order to identify possible differences in the physiological potential of seed lots having a similar germination. The electrical conductivity test has been widely accepted and used for this purpose and is capable of quickly estimating potential seed performance in the field by assessing the rate of solute leachates, such as amino acids and inorganic ions, which reflect the degree of cell membrane organization (Powell, 1986).

More recently automated techniques have been proposed to obtain additional information on seed physiological potential, including the automated image analysis of seedlings (Seed Vigor Imaging System - SVIS), developed by Sako et al. (2001). Reproducible results were obtained by Hoffmaster et al. (2003) and Marcos-Filho et al. (2009) for soybean seeds, Xu et al. (2007) for cotton seeds, and Marcos-Filho et al. (2006) for melon seeds. An additional advantage of the SVIS is its low-cost compared to traditional vigor tests.

The objective of the present study was to verify the efficiency of the SVIS in association with the electrical conductivity test, to detect differences in vigor between lots of sun hemp seeds.

\section{Material and Methods}

The experiments were conducted between June 2009 and July 2010 at the Seed Analysis Laboratory of São Paulo State University (UNESP), Jaboticabal campus, SP and in the Image Analysis Laboratory of São Paulo University (USP/ESALQ), Piracicaba campus, SP, Brazil. Five lots of sun hemp seeds were supplied by different commercial companies. The initial seed water content varied between 11.5 to $12.3 \%$ on a fresh weight basis. Seed lots were kept in multi-layered Kraft paper containers and stored in a cold chamber at $10{ }^{\circ} \mathrm{C}$ and $60 \%$ relative air humidity during the experimental period.

Seed water content - this was determined by the oven method, at $105 \pm 3{ }^{\circ} \mathrm{C}$ for $24 \mathrm{~h}$ (Brasil, 2009), with two replicates of 50 seeds for each lot. Results were expressed as a percentage on a fresh weight basis.

Germination - four replications of 50 seeds each per lot were placed on sand in plastic boxes $(28.5 \times 18.5 \mathrm{x}$ $10.0 \mathrm{~cm}$ ), and kept at $20-30{ }^{\circ} \mathrm{C}$. Data were recorded at four and ten days after sowing; results were expressed as a percentage of normal seedlings (Brasil, 2009).

Saturated salt accelerated aging test (SSAA) - the procedure proposed by Jianhua e McDonald (1996) for small seeds was used as the standard comparison. About $18 \mathrm{~g}$ of seeds per lot were distributed in a single layer on a stainless steel mesh inside transparent plastic boxes (11 x $11 \times 3.5 \mathrm{~cm})$, containing $40 \mathrm{~mL}$ of a saturated solution of $\mathrm{NaCl}(40 \mathrm{~g} / 100 \mathrm{~mL}$ of water), resulting in an internal relative air humidity of $76 \%$. The boxes were closed and kept in aging chambers, enclosed by a water jacket at $41{ }^{\circ} \mathrm{C}$, for 96 hours. Following the aging treatment, four replications of 50 seeds each per lot were set to germinate (Brasil, 2009). An evaluation was made four days after sowing by calculating the percentage of normal seedlings. Seed water content after aging was also determined to observe the uniformity of the test conditions and varied between 12.4 and $14.3 \%$.

Electrical conductivity - this was determined by the weight method, with four replications of 50 seeds each per lot. Seed samples were weighed ( $0.1 \mathrm{~g}$ accuracy) and placed in plastic cups $(200 \mathrm{~mL})$ containing $75 \mathrm{~mL}$ of distilled water. The containers were then covered with cellophane and kept at $25{ }^{\circ} \mathrm{C}$ for $1,2,4,8$ and $16 \mathrm{~h}$, to establish the most suitable period for classifying lots with different vigor levels. The electrical conductivity of the solution was measured by using a DIGIMED DM-32 conductivity meter and the results were expressed in relation to the seed weight $\left(\mu \mathrm{S} . \mathrm{cm}^{-1} \cdot \mathrm{g}^{-1}\right)$ (Marcos-Filho and Vieira, 2009).

Field seedling emergence - four subsamples of 50 seeds per lot were planted in seed beds in the field, in $1.5 \mathrm{~m}$ long rows with $0.25 \mathrm{~m}$ between rows. Evaluations were made 10 days after sowing and the results expressed 
as a percentage of emerged seedlings (Nakagawa, 1999).

Seed Vigor Imaging System (SVIS) - four replications of 25 seeds were used for each lot. The seeds were placed in two horizontal rows on the upper third of the surface of previously moistened paper towels so that the primary root could grow downwards. The towels were rolled up and transferred to a germination chamber at $20-30{ }^{\circ} \mathrm{C}$ and kept for three or four days in continuous light. Seedlings were then arranged on a sheet of black pasteboard, set on the surface of an aluminium box (60 x $50 \times 12 \mathrm{~cm})$, inside of which was an HP Scanjet 2004 scanner, placed upside down and operated by a Photosmart software with a 98 dpi resolution. The seedling images were digitalized and analyzed by the SVIS software, which calculated data on the vigor index and seedling growth and uniformity. The vigor index was generated by a combination of growth parameters ( $70 \%$ contribution) and seedling uniformity (30\% contribution), both based on the maximum possible length of the sun hemp seedlings three and four days after sowing (maximum values of 3.5 and 4.5 inches were estimated, respectively after preliminary tests). Results were expressed as mean values obtained for each seed lot.

Statistical analysis - the data from each test were analyzed separately by analysis of variance in a completely randomized design and the means compared by the Tukey test $(\mathrm{p} \leq 0.05)$.

\section{Results and Discussion}

The germination percentage of all the lots was acceptable for the commercialization of sun hemp seeds, which is fixed at 60\% in Brazil (Brasil, 2008) (Table 1), demonstrating that the seed lots had a high germinative capacity under favorable environmental conditions. Final germination percentages and the first germination counts gave similar results in differentiating lot performance, with the first counts at 4 days varying between 69 and $82 \%$ and the final germination at 10 days between 82 and $93 \%$, with both detecting only a lower quality in lot 5 .

Table 1. Germination and vigor evaluated by the first germination count, accelerated aging and field seedling emergence of five lots of Crotalaria seeds.

\begin{tabular}{|c|c|c|c|c|}
\hline Lots & Germination & First germination count & $\begin{array}{l}\text { Saturated salt accelerated } \\
\text { aging }\end{array}$ & Field seedling emergence \\
\hline & \multicolumn{4}{|c|}{--------------------------------------------------------- } \\
\hline 1 & $93 \mathrm{a}$ & $82 \mathrm{a}$ & $91 \mathrm{a}$ & $85 \mathrm{a}$ \\
\hline 2 & $90 \mathrm{ab}$ & $79 \mathrm{ab}$ & $87 \mathrm{ab}$ & $84 \mathrm{a}$ \\
\hline 3 & $89 \mathrm{ab}$ & $74 \mathrm{ab}$ & $70 \mathrm{c}$ & $78 \mathrm{a}$ \\
\hline 4 & $93 \mathrm{a}$ & $80 \mathrm{a}$ & $84 \mathrm{ab}$ & 89 a \\
\hline 5 & $82 \mathrm{~b}$ & $69 \mathrm{~b}$ & $79 \mathrm{bc}$ & $74 \mathrm{a}$ \\
\hline C.V. (\%) & 4.5 & 6.2 & 5.2 & 8.8 \\
\hline
\end{tabular}

(*) Comparison of means within each column (Tukey test, $\mathrm{p} \leq 0.05$ )

The accelerated aging test was able to identify differences in vigor (Table 1). Lots 1, 2 and 4 showed a higher potential than lot 3 . On the other hand, the field seedling emergence test was unable to evaluate seed physiological potential (Table 1), indicating that experimental field conditions were not sufficiently unfavorable to promote differences in seed lots with a similar germination.

The vigor parameters, such as the vigor index and seedling growth and uniformity, assessed in 3-day old seedlings by the SVIS (Table 2), showed higher values in lots 2, 3 and 4 compared to the lower performance of lot 5 . The results of the automated analysis of the seedling images by the SVIS for 4-day old seedlings (Table 2) were very variable, with a an increase in the coefficients of variation for the vigor index and seedling growth parameters, making the identification of consistent differences between seed lots difficult; lot 5 was identified as having the worst performance according to the vigor index and seedling length parameters (Figure1). 
Table 2. Vigor index, growth uniformity and seedling length ( $\mathrm{mm}$ ) in five lots of Crotalaria seeds after three and four days obtained from the automated evaluation system of seed vigor (SVIS).

\begin{tabular}{ccccccc}
\hline Lots & $\begin{array}{c}\text { Vigor } \\
\text { index } \\
(3 \text { days })\end{array}$ & $\begin{array}{c}\text { Growth } \\
\text { uniformity } \\
(3 \text { days })\end{array}$ & $\begin{array}{c}\text { Seedling length } \\
\text { (3 days) }\end{array}$ & $\begin{array}{c}\text { Vigor } \\
\text { index } \\
(4 \text { days })\end{array}$ & $\begin{array}{c}\text { Growth } \\
\text { uniformity } \\
(4 \text { days })\end{array}$ & $\begin{array}{c}\text { Seedling length } \\
(4 \text { days })\end{array}$ \\
\hline 1 & $577 \mathrm{bc}$ & $814 \mathrm{~b}$ & $19 \mathrm{bc}$ & $637 \mathrm{ab}$ & $867 \mathrm{a}$ & $21 \mathrm{ab}$ \\
2 & $706 \mathrm{ab}$ & $830 \mathrm{ab}$ & $26 \mathrm{ab}$ & $754 \mathrm{ab}$ & $844 \mathrm{a}$ & $28 \mathrm{ab}$ \\
3 & $792 \mathrm{a}$ & $894 \mathrm{a}$ & $30 \mathrm{a}$ & $770 \mathrm{a}$ & $840 \mathrm{a}$ & $29 \mathrm{ab}$ \\
4 & $706 \mathrm{ab}$ & $857 \mathrm{ab}$ & $25 \mathrm{abc}$ & $775 \mathrm{a}$ & $867 \mathrm{a}$ & $29 \mathrm{a}$ \\
5 & $554 \mathrm{c}$ & $797 \mathrm{~b}$ & $18 \mathrm{c}$ & $546 \mathrm{~b}$ & $849 \mathrm{a}$ & $18 \mathrm{~b}$ \\
\hline C.V. $(\%)$ & 9.2 & 4.2 & 14.9 & 13.7 & 3.3 & 20.9 \\
\hline
\end{tabular}

$(*)$ Comparison of means within each column (Tukey test, $\mathrm{p} \leq 0.05$ )

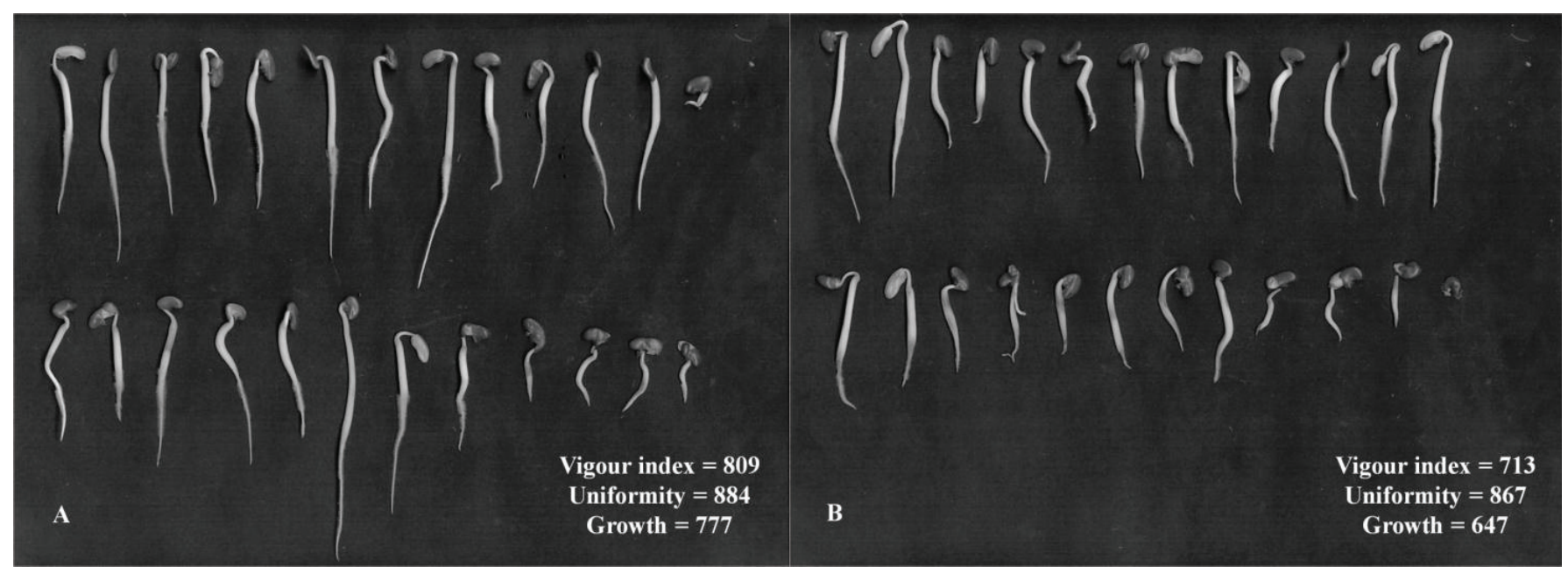

Figure 1. Digital images of Crotalaria seedlings three days after sowing from a repetition of high and low vigor lots, lots 3 (A) and 5 (B), respectively, analyzed by the automated evaluation system of seed vigor (SVIS).

Results of the electrical conductivity test (Table 3) varied between 11.7 and $141.7 \mu \mathrm{S} . \mathrm{cm}^{-1} . \mathrm{g}^{-1}$, after 1 to 16 hours of imbibition respectively; a clear distinction of the seed lot physiological potential was detected after 1 hour of imbibition, similar to results obtained from the SVIS on 3-day old seedlings, where lots 2, 3 and 4 showed the best vigor and lot 5 the worst. However, the results for imbibition periods of 4 and 8 hours were more uniform with relatively lower coefficients of variation.

The lower capacity of cellular membranes to reorganize during the hydration process as well as the difficulty in repairing membrane damage due to the rapid absorption of water, showed a close relationship with the vigor parameters analyzed by the SVIS, since there was a decrease in the vigor index, seedling length and growth uniformity with an increase in electrical conductivity (Tables 2 and 3). Thus, considering an hour of seed soaking, the leachate concentration of 11.7 $\mu \mathrm{S} . \mathrm{cm}^{-1} \cdot \mathrm{g}^{-1}$ (lot 3) (Table 3) was reflected in a vigor index of 792 and seedling uniformity and length of 894 and $30 \mathrm{~mm}$, respectively, for 3-day old seedlings (Table 2), whereas solute losses of $21.3 \mu \mathrm{S} . \mathrm{cm}^{-1} \cdot \mathrm{g}^{-1}$ (lot 5) (Table 3), resulted in a vigor index of 554, a growth uniformity of 797 and $18 \mathrm{~mm}$ long seedlings (Table 2).

Therefore, a relationship between the quantity of leached products lost by the seed and the seedling growth potential detected by the SVIS was observed. This confirms the hypothesis proposed by Heydecker (1972) and Delouche and Baskin (1973), emphasizing that membrane degeneration and decreases in seedling development are closely associated during the seed deterioration process. 
Table 3. Relationship between the electrical conductivity $\left(\mu \mathrm{S} \cdot \mathrm{cm}^{-1} \cdot \mathrm{g}^{-1}\right)$ of five Crotalaria seed lots and the imbibition period.

\begin{tabular}{cccccc}
\hline \multirow{2}{*}{ Lots } & \multicolumn{5}{c}{ Electrical conductivity } \\
\cline { 2 - 6 } & $1 \mathrm{~h}$ & $2 \mathrm{~h}$ & $4 \mathrm{~h}$ & $8 \mathrm{~h}$ & $16 \mathrm{~h}$ \\
\hline 1 & $18.4 \mathrm{bc}$ & $28.7 \mathrm{bc}$ & $51.7 \mathrm{bc}$ & $92.3 \mathrm{bc}$ & $122.5 \mathrm{a}$ \\
2 & $13.4 \mathrm{a}$ & $20.1 \mathrm{a}$ & $43.0 \mathrm{ab}$ & $80.1 \mathrm{a}$ & $112.4 \mathrm{a}$ \\
3 & $11.7 \mathrm{a}$ & $17.9 \mathrm{a}$ & $40.0 \mathrm{a}$ & $82.7 \mathrm{ab}$ & $115.8 \mathrm{a}$ \\
4 & $15.3 \mathrm{ab}$ & $23.1 \mathrm{ab}$ & $45.1 \mathrm{ab}$ & $83.6 \mathrm{ab}$ & $117.1 \mathrm{a}$ \\
5 & $21.3 \mathrm{c}$ & $32.7 \mathrm{c}$ & $59.3 \mathrm{c}$ & $101.1 \mathrm{c}$ & $141.7 \mathrm{~b}$ \\
\hline C.V. (\%) & 14.7 & 12.9 & 6.3 & 5.6 & 5.0 \\
\hline
\end{tabular}

(*) Comparison of means within each column (Tukey test, $\mathrm{p} \leq 0.05$ )

The efficiency of the SVIS software in evaluating seed vigor has been observed in the seeds of various species, such as lettuce (Sako et al., 2001; Peñaloza et al., 2005), soybean (Hoffmaster et al., 2003; MarcosFilho et al., 2009) and melon (Marcos-Filho et al., 2006). Hoffmaster et al. (2003) and Marcos-Filho et al. (2009) also demonstrated the potential of this software in evaluating the vigor of soybean seeds using 3-day old seedlings. The electrical conductivity test has been standardized for other leguminous seeds (Vieira et al., 2004; Artola and Carrillo-Castañeda, 2005; Muasya et al., 2006). Nakagawa et al. (2003) proposed a 24 hour imbibition period at $20^{\circ} \mathrm{C}$ for sun hemp seeds to determine seed vigor. In the present study, a 1 hour period of seed imbibition in water at $25{ }^{\circ} \mathrm{C}$ was enough to separate the different lots for vigor with reproducible results, whereas an imbibition period of 16 hours or more caused primary root protrusion, which directly influenced the leaching rate of the exudates. However, when the leaching rate of the exudates in the imbibition solution was measured after 4 or 8 hours, the leaching stability was less variable and there was a consequent reduction in the coefficients of variation.

Therefore, the evaluation of vigor in sun hemp seeds can be made easily and accurately combining both the SVIS and electrical conductivity readings of the seed imbibition solution. This software, associated with the electrical conductivity test, can be included in seed quality control programs and aid in decision making at different stages of production and use of sun hemp seeds, supplying valuable data on the degree of deterioration, initial growth potential and uniformity of seedling emergence, which are primary components for the successful field establishment of plants.

\section{Conclusions}

The software SVIS and electrical conductivity are promising for evaluating the physiological potential of sun hemp seeds.

SVIS obtains reproducible results by digital image analysis of 3-day old seedlings.

The electrical conductivity should be carried out using 50 seeds placed in $75 \mathrm{~mL}$ of deionised water at $25^{\circ} \mathrm{C}$ with 4 or 8 hours of seed soaking.

\section{Acknowledgements}

To FAPESP (Fundação de Amparo à Pesquisa do Estado de São Paulo), CAPES (Coordenação de Aperfeiçoamento de Pessoal de Nível Superior) and CNPq (Conselho Nacional de Desenvolvimento Científico e Tecnológico) for financial support and to the seed companies. Wolf Seeds do Brasil S.A., J.C. Maschietto Ltda, Piraí Sementes and Seprotec for supplying the seeds.

\section{References}

ARTOLA, A.; CARRILLO-CASTAÑEDA, G. The bulk conductivity test for birdsfoot trefoil seed. Seed Science and Technology, v.33, p.231-236, 2005. http://www.ingentaconnect.com/content/ista/ sst/2005/00000033/00000001/art00023

BRASIL. Ministério da Agricultura, Pecuária e do Abastecimento. Instrução Normativa n. 30, de 21 de maio de 2008. (Estabelece os padrões para produção e comercialização de sementes de espécies forrageiras de clima tropical). Diário Oficial da União, Poder Executivo, Brasília, DF, Anexo IV, 23 maio 2008. http://extranet.agricultura.gov.br/sislegis-consulta/servlet/ VisualizarAnexo?id=14240. Acesso em 05 fev. 2011.

BRASIL. Ministério da Agricultura, Pecuária e Abastecimento. Regras para 
análise de sementes. Ministério da Agricultura, Pecuária e Abastecimento. Secretaria de Defesa Agropecuária. Brasília: MAPA/ACS, 2009. 395p.

DELOUCHE, J.C.; BASKIN, C.C. Accelerated aging techniques for predicting the relative storability of seed lots. Seed Science and Technology, v.1, p.427-452, 1973.

HEYDECKER, W. Vigor. In: ROBERTS, E.H. Viability of seeds. Syracuse University Press, 1972. p.204-252.

HOFFMASTER, A.L.; FUJIMURA, K.; McDONALD, M.B.; BENNETT, M.A. An automated system for vigor testing three-day-old soybean seedlings. Seed Science and Technology, v.31, p.701-713, 2003. http://cat.inist.fr/?aModele $=$ afficheN\&cpsidt $=15163127$

JIANHUA, Z.; McDONALD, M.B. The saturated salt accelerated aging test for small-seeded crops. Seed Science and Technology, v.25, p.123131, 1997. http://cat.inist.fr/?aModele=afficheN\&cpsidt=2682143

MARCOS-FILHO, J.; VIEIRA, R.D. Seed Vigor Tests: Principles Conductivity Tests. In: RIAD BAALBAKI; SABRY ELIAS; JULIO MARCOS-FILHO; MILLER B. McDONALD. (Org.). Seed Vigor Testing Handbook. Contribuition $\mathrm{n}^{\circ} 32$ to the Handbook on Seed Testing, Ithaca, NY, USA: AOSA, 2009, p.77-90.

MARCOS-FILHO, J.; KIKUTI, A.L.P.; LIMA, L.B. Métodos para avaliação do vigor de sementes de soja, incluindo a análise computadorizada de imagens. Revista Brasileira de Sementes, v.31, p.102-112, 2009. http://www.scielo.br/pdf/rbs/v31n1/a12v31n1.pdf

MARCOS-FILHO, J.; BENNETT, M.A.; McDONALD, M.B.; EVANS, A.F.; GRASSBAUGH, E.M. Assessment of melon seed vigor by an automated computer imaging system compared to traditional procedures. Seed Science and Technology, v.34, p.485-497, 2006. http://www. ingentaconnect.com/content/ista/sst/2006/00000034/00000002/art00023

MUASYA, R.M.; LOMMEN, W.J.M.; AUMA, E.O.; STRUIK, P.C. Evaluation of variation in individual seed electrical conductivity in common bean (Phaseolus vulgaris) seed lots. Seed Science and Technology, v.34, p.621-632, 2006. http://www.ingentaconnect.com/ content/ista/sst/2006/00000034/00000003/art00009
NAKAGAWA, J. Testes de vigor baseados no desempenho das plântulas. In: KRZYZANOSKI, F.C.; VIEIRA, R.D.; FRANÇA-NETO, J.B. (Ed.). Vigor de sementes: conceitos e testes. Londrina: ABRATES, 1999. p.2.1-2.24.

NAKAGAWA, J.; COIMBRA, R.A.; CAVARIANI, C. Teste de condutividade elétrica em sementes de Crotalaria juncea L.: Influência do tamanho e da coloração das sementes. Científica, v.31, p.157-166, 2003.

PEÑALOZA, P.; RAMIREZ-ROSALES, G.; McDONALD, M.B.; BENNETT, M.A. Lettuce (Lactuca sativa L.) seed quality evaluation using seed physical attributes, saturated salt accelerated aging and the seed vigor imaging system. Electronic Journal of Biotechnology, v.8, p.299-307, 2005. http://www.scielo.cl/pdf/ejb/v8n3/a10.pdf

POWELL, A.A. Cell membranes and seed leachate conductivity in relation to the quality of seed for soaking. Journal Seed Technology, v.10, p.81-100, 1986.

SAKO, Y.; McDONALD, M.B.; FUJIMURA, K.; EVANS, A.F.; BENNETT, M.A. A system for automated seed vigor assessment. Seed Science and Technology, v.29, p.625-636, 2001. http://cat.inist.fr/?aMod ele $=$ afficheN\&cpsidt $=14110910$

VIEIRA, R.D.; SCAPPA NETO, A.; BITTENCOURT, S.R.M.; PANOBIANCO, M. Electrical conductivity of the seed soaking solution and soybean seedling emergence. Scientia Agricola, v.61, p.164-168, 2004. http://www.scielo.br/pdf/sa/v61n2/19357.pdf

WANG, Q.; KLASSEN, W.; LI, Y.; CODALLO, M. Cover crops and organic mulch to improve tomato yields and soil fertility. Agronomy Journal, v.101, p.345-351, 2009. http://scholar.googleusercontent.com/ scholar? $\mathrm{q}=$ cache:XAphkh4NA8sJ:scholar.google.com/+cover + crops $+\mathrm{a}$ $\mathrm{nd}+$ organic + mulch + to + improve + tomato + yields + and + soil + fertility \& $\mathrm{hl}=$ pt-BR\&as_sdt $=0$ \&as_vis $=1$

XU, L.; FUJIMURA, K.; McDONALD, M.B. Automatic separation of overlapping seedlings by network optimization. Seed Science and Technology, v.35, p.337-350, 2007. http://www.ingentaconnect.com/ content/ista/sst/2007/00000035/00000002/art00009 